\title{
METHOD OF ASSESSMENT OF TRANSPORTATION COMPETITIVENESS ON BASIS OF MULTIPLE VECTOR MODEL OF TRANSPORTATION SERVICES QUALITY INDICATORS
}

\author{
O. M. Zagurskiy
}

National University of Life and Environmental Sciences of Ukraine, Ukraine.

Speciality of article: 275 - transport technologies (by road).

Corresponding author: zagurskiy_oleg@ukr.net.

Article history: Received-August 2020, Accepted-October 2020.

Bibl. 10, fig. 6, tabl. 0 .

Abstract. Competitiveness indicators for transport services are changing under the influence of both intraindustry factors and the conditions of the transport market and macroeconomic conditions. At the same time, under the conditions of continuous improvement of quality and differentiation of transport services of the competing companies, the requirements put forward by freight owners to trucking companies change.

The article proposes a new method of assessing the competitiveness of a motor transport company by the transport service quality indicators. The developed model allows to assess the competitiveness of the motor transport enterprise on the basis of the transport service quality indicators, taking into account both the importance of the individual factors of quality in the general system and their various changes.

This model can be used to provide an indicative assessment of the quality of transportation in various segments of the freight market.

Key words: efficiency, competitiveness, freight, transport services, quality of service.

\section{Introduction}

The study of the quality of road transport services is possible using different approaches, for example, both from the point of view of the process of rendering the road service and from the point of view of the consumption of the road service. If the road transport service is provided by qualified enterprises under the conditions that meet all the requirements of scientific and technological progress, then, all else being equal, the result will be the best, and therefore the quality level will be the highest.

\section{Formulation of problem}

This view takes into account three components of the quality of road transport services: quality of the structure (organizational and technical quality of resources: material and technical base, staffing, etc.); the quality of the process (timely delivery of goods and passengers, the choice of an adequate strategy of technology of rendering services, compliance with rules and standards, etc.); quality of the result (socio-economic effect of the measures taken).

\section{Analysis of recent research results}

Recently, based on the specific nature of services, scientists seek to distinguish from the general concepts of enterprise competitiveness - the competitiveness of the service industry. Thus, I.V. Dragunov concludes that the competitiveness of a service organization is determined by its potential, sufficient to retain or expand its market share in a competitive environment [2]. B. Seyoum's competitiveness of organizations in the sphere of transport and tourist services is determined by their comparative advantages over their competitors [9]. Instead, W. Song and C. Pang point out that the competitiveness of the service sector is primarily determined by the quality of the services provided. In particular, the impact of quality is stronger for large companies and when the global environment is characterized by high dynamism and complexity [10].

Based on the specific nature of road transport services, the methods of assessing their competitiveness also have some differences. Their study is given the attention of T.A. Vorkut, O.E. Bilonog, A.M. Dmitrychenko and Yu.O. Tretynichenko [1], O.I. Zorina, O.V. Sivolovskaya [6], V.G. Shynkarenko, T.E. Lazarev [8]. Some aspects of this problem have been considered by us in previous works [3, 4].

However, the breadth of tasks entrusted to the road transport market, especially in terms of improving the quality of transport services, requires further research in this area.

\section{Purpose of research}

The purpose of the work is to develop a method of assessing the competitiveness of the motor transport company by the quality of transport service. 


\section{Research results}

Almost all developments in the field of assessment and quality assurance of road transport services are in one way or another related to the use of such approaches as structural, process and effective. It is also important to note that such categories as "price" and "quality" are closely linked, but quality is one of the determining factors in the competitive struggle of motor transport companies for the consumer of services. Therefore, assessment is the final part of quality management, which involves analyzing the economic and social effectiveness of the road transport services provided. Social efficiency has a broader meaning.

The criteria for social efficiency are indicators of the country's (region's) development and satisfaction of the population with the received motor transport services. Cost-effectiveness is determined by the ratio of effect (output) and cost. Cost-effectiveness analysis is necessary to improve the quality of services when the most important problem is to achieve maximum results with limited costs.

Competitiveness indicators for transport services are changing under the influence of both intra-industry factors and the conditions of the transport market and macroeconomic conditions. At the same time, under the conditions of continuous improvement of quality and differentiation of transport services of the competing companies, the requirements put forward by freight owners to motor transport companies change. Accordingly, only the users of transport services can give the most objective assessment of the competitiveness of a motor transport enterprise in terms of quality of transport service.

In this case, it is advisable to use a graphical method to perform analysis on specific indicators. Its advantage is a visual representation of all indicators, which allows to analyze their dynamics both mathematically and visually. The disadvantage is the inability to account for the impact of individual quality indicators in the overall system. That is, a differentiated change of individual indicators towards improvement or deterioration may not affect the complex indicator, which is geometrically expressed by the area of the figure.

In this method, the competitiveness of road transport can theoretically be represented on a plane in the form of a multidimensional coordinate system, in which specific indicators of the quality of transportation are distinguished, the quantity of which may be unlimited (a1... a2 ... ai) (see Fig. 1).

In the transition from the theoretical model to the practical assessment, the number of analyzed indicators is limited by the available statistical information on the quality of freight traffic and the quality of transport services.

At the same time, for the convenience of competitiveness analysis and ensuring the comparability of all indicators, the measurement of indicators is carried out in the range from 0 to 1 (a value equal to 1 , which corresponds to the provision of regulatory or planned level of the indicator). Therefore, even when the figure exceeds one, it is considered equal to 1 .

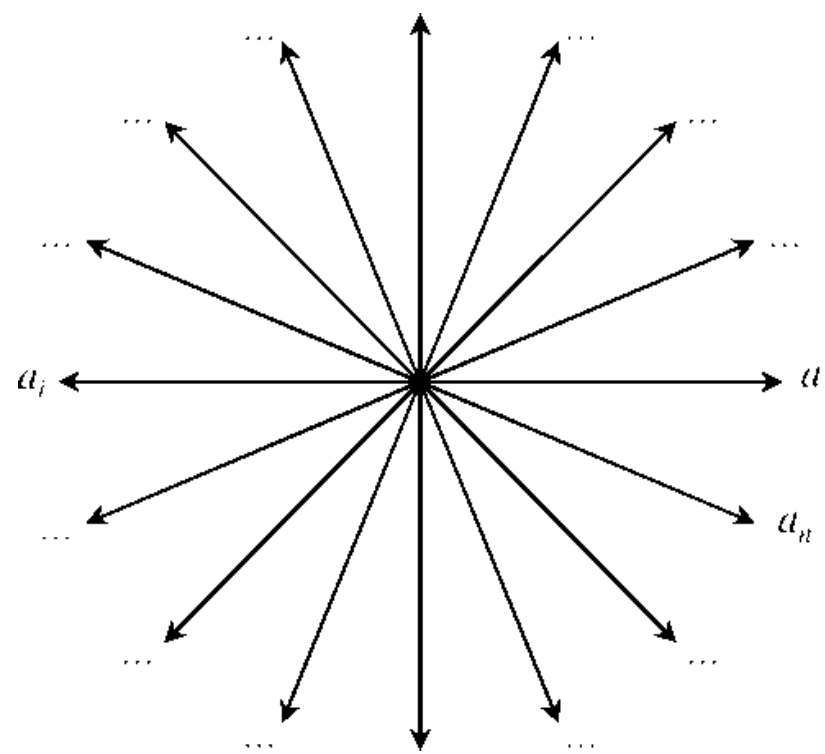

Fig. 1. Multidimensional coordinate system for the quality of road transport.

Source: Compiled by the authors.

In our view, the quality of transport services is fully characterized by the following system of indicators:

- delivery time;

- safety;

- security;

- completeness of transportation demand satisfaction;

- regularity (rhythm) of cargo delivery;

- comprehensiveness of transport services;

- transport accessibility of users;

- transport security of the territories;

- environmentally friendly transportation.

So, we build an n-dimensional system of transport service quality in space (Fig. 2).

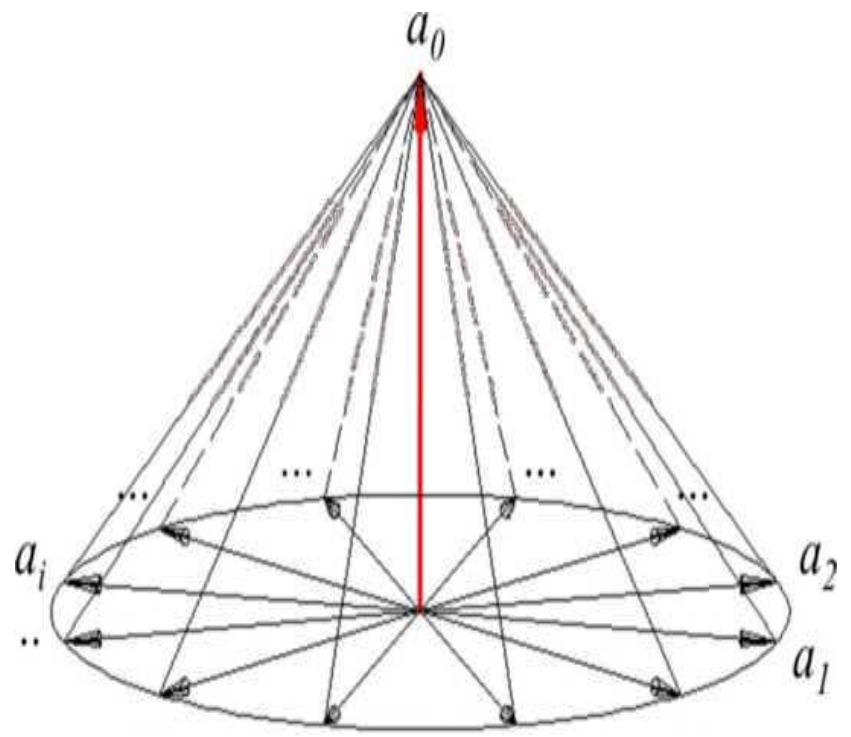

Fig. 2. Spatial pattern of the transport service quality system.

Source: Compiled by the authors.

To do this, we select the principal analyzed parameter a0 and depict it as a vector emerging from the origin of this system and pointing upward perpendicular 
to the horizontal plane in which the other vectors are located. They will display metrics that can be analyzed in two-dimensional space (a1, a2, ..., ai).

The spatial model allows us to obtain an additional parameter - the total vector of the асум which length and direction in space allows us to assess the complex change of the analyzed indicators. The total vector is determined by the formula:

$$
a_{c o m}=\sum_{i=1}^{n} \bar{a}_{i}+\bar{a}_{0}
$$

Therewith, $\sum \bar{a}_{i}$ is a projection of $a_{\text {com }}^{-}$vector on a horizontal plane, as $a_{0}$ vector; is perpendicular to this plane.

As can be seen from Fig. 3, the figure formed by the connection of the end of $a_{0}$ vector; with the ends of the projection vectors, will be an n-corner pyramid.

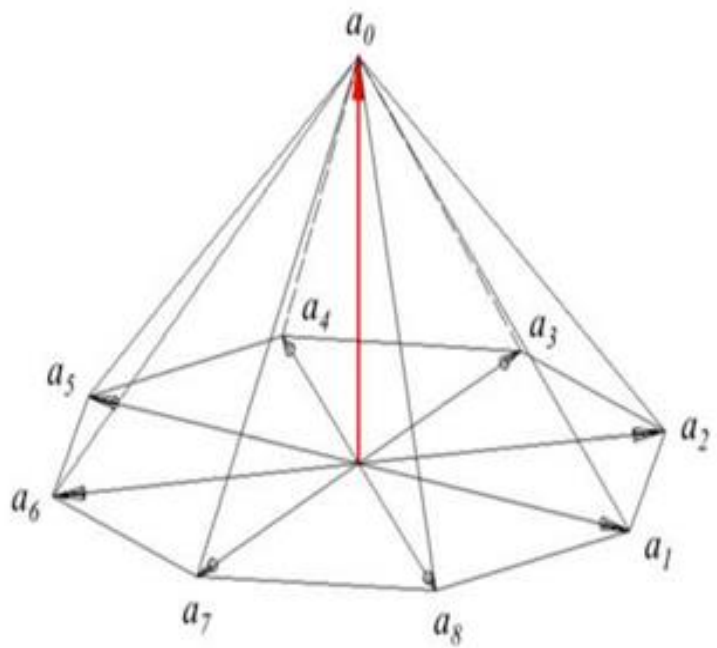

Fig. 3. Spatial pattern of the equilibrium system of service quality indicators.

Source: Compiled by the authors.

The angles between the vectors lying on the plane can be determined by the formula:

$$
a_{i}=\frac{360}{n}=\text { const }
$$

In this case, the correct n-angular figure can be obtained only in the case of equilibrium influence of quality indicators on competitiveness, in which all indices a1 ... ai are equal in modulus, and the total vector $a_{c y M}$ coming from the origin will coincide with the vector $a_{0}$ and will play a role of height in this pyramid, being clearly perpendicular to the plane, because in this case $\sum \bar{a}_{i}=0$. Let's call this vector $a_{c y M}^{-}$"perfect". This equality will also be observed when the number of indices analyzed on the plane is equal, if the values of all pairwise opposite vectors are equal in modulus.
Based on the analysis of the theory and practice of assessing the quality of freight traffic, it is advisable to send upward a vector that characterizes the indicator of reliability of cargo delivery as the most significant, and to consider other indicators on the plane. It provides an opportunity to assess their importance in the system and identify problem areas that need priority.

As the basic indicators of competitiveness of freight transportation are reduced to eight summarizing indicators of quality of transport service, using a multidimensional spatial vector, let us imagine in space a multidimensional coordinate system consisting of eight axes on a plane, and the vector of reliability of supply itself $a_{0}$; will be clearly perpendicular to the plane. The total area of the figure can be determined by the formula:

$$
S_{\text {com }}=\sum_{i=1}^{n} S_{a_{i}, a_{i+1}}=\frac{1}{2} \sum_{i=1}^{n} a_{i} \times a_{i+1} \times \sin \alpha_{i}
$$

By analyzing changes in metrics over a period of time, you can compare the areas of the resulting figures for each period. However, this comparison does not allow us to assess the impact of individual indicators on the overall system.

In contrast to the plane model, in the spatial model, in addition to the parameter of the area, there is a deviation of the total vector from the vertical, which is characterized by the vector of its projection onto the plane. The less actual quality indicators are balanced, the greater the deviation of the total vector from the vertical, i.e.

$$
\sum a_{i} \neq 0
$$

where $a_{\text {tot }}$ is the "perfect" total vector,

$a_{\text {tot }} \quad$ is the actual total vector.

Thereat, the deviation $a_{\text {tot }}$ from $a_{\text {tot }}$ indicates what quality indicators will negatively affect the complex competitiveness indicator.

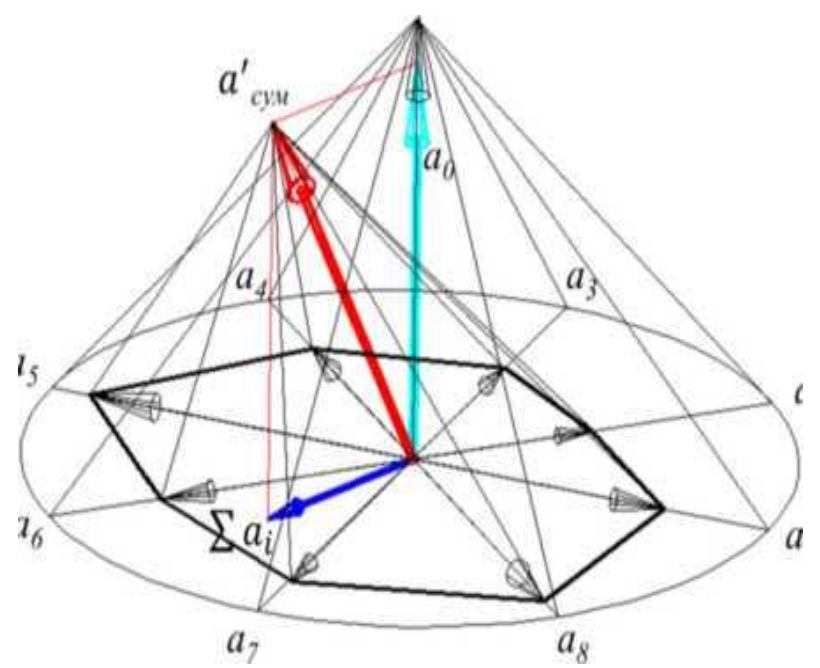

Fig. 4. Spatial pattern of the nonequilibrium system of service quality indicators.

Source: Compiled by the authors. 
To determine the parameters of the total vector $a_{c o m}$ and its projections $\sum \bar{a}_{i}$, we use relations from vector algebra [5].

1) The coordinates of the total vector $a_{c o m}$ are determined by of the following formulas:

$$
\begin{gathered}
X=\sum_{i=1}^{n} a_{i} \times \cos \left(a_{i} \times(i-1)\right) \\
Y=\sum_{i=1}^{n} a_{i} \times \sin \left(a_{i} \times(i-1)\right), \\
Z=a_{0}
\end{gathered}
$$

where $\mathrm{x}, \mathrm{y}, \mathrm{z}$ - are the coordinates of the total vector;

$\mathrm{a}_{\mathrm{i}}-$ is the value of the $\mathrm{i}$-th quality indicator;

$\alpha_{i-}$ is the angle formed by vectors.

Thus, if $\sum \bar{a}_{i}=0$, then $\mathrm{x}=0$ and $\mathrm{y}=0, \mathrm{z}=\alpha_{0}$, the coordinates of the projection of the total vector on the plane will take the value $(x ; y ; 0)$.

2) The length of the total vector $a_{c y M}$ and its projection $\sum \bar{a}_{i}$ are determined $\mathrm{b} \mathrm{y}$ the formulas:

$$
\begin{aligned}
& l_{a_{t o t}}=\sqrt{x^{2}+y^{2}+a_{0}^{2}}, \\
& l_{\sum_{-} a_{i}}=\sqrt{x^{2}+y^{2}},
\end{aligned}
$$

3) The angle $\beta$ between the vector and the horizontal plane is determined by the formula:

$$
\operatorname{tg} \beta=\frac{\left|\overline{a_{0}}\right|}{\left|\sum a_{i}\right|},
$$

4) To determine the angle $\gamma$, which shows the direction of projection of the total vector on the plane, you can use the formula:

$$
\operatorname{tg} \gamma=\frac{y}{x}
$$

And since it is not always possible to accurately visually determine in which segment the projection of the total vector lies, it is advisable to quantify the position of

the plane formed by the total vector $a_{\text {tot }}$ and the main vector $a_{0}$ by the angle $\gamma$.

Given the length of the total vector and the angle between it and the horizontal plane, the system of criteria for maximizing the quality level is presented as follows:

$$
l a_{c e v} \rightarrow 1, \beta \rightarrow 90
$$

The position of the vector $\sum \bar{a}_{i}$ on the plane allows you to determine the segment in which the quality indicators have a negative impact on the complex indicator of competitiveness. The direction of the projection of the total vector indicates a segment where positive dynamics of quality indicators were observed, and the opposite end of this projection - to a segment with indicators that lag behind the complex dynamics of growth.

As already mentioned, it is important for the distribution of factors in the coordinate system to structure them according to the nature of the analysis. Thus, for analysis from the point of view of the freight enterprise, a multidimensional system with structured quality of transport service on the plane will take the following form (Fig. 5).

The analyzed indicators are divided into two groups:

- indicators of completeness of transport service (speed or term of delivery of cargo; completeness of transportation demand satisfaction; fulfillment of supply conditions; complexity of transport service; transport accessibility of users);

- indicators of stability of transport services (regularity or rhythm of delivery of goods, availability of vehicles, condition of vehicles, safety of transported goods, safety of transportation; transport security of the territory).

It should be noted that the proposed system also takes into account such indicators as transportation security and accessibility, which are not directly dependent on the activity of the freight enterprise, but do not take into account the environmental indicator, since it is not directly relevant for each specific type of cargo and, accordingly, its owner. In this case, the quality of transport services and, in general, the competitiveness of freight traffic will be influenced by the zone of overwhelming influence of the carrier and the zone of overwhelming influence of the owner of the infrastructure.

The use of freight transport service providers to characterize the quality of freight transport indicators is fundamentally important not only from the point of view of market practice, because it reflects the principle of customer orientation, but also from the point of view of fundamental provisions of economic theory. Another founder of the

Austrian School of Economics, K. Menger, emphasized that the value of benefits is "the judgments that managers have about the value of the goods at their disposal" [7]. In our view, K. Menger's proposition underlying the subjective theory of value fully applies to the assessment of the individual qualities of these goods, in particular, the quality of freight.

We analyze the parameters $\left(a_{1} \div a_{12}\right)$ on the plane, grouping them in the following directions: completeness of transport service, speed and regularity of deliveries, stability of transport service, interaction with users of transport services

As the main parameter that goes up from the origin, we choose "cost of services" $\left(\mathrm{a}_{0} ;\right)$.

Thus, the formed system will comprehensively characterize the price and quality of transportation, and the vectors characterizing the quality indicators will be located in the horizontal plane (Fig. 6). 


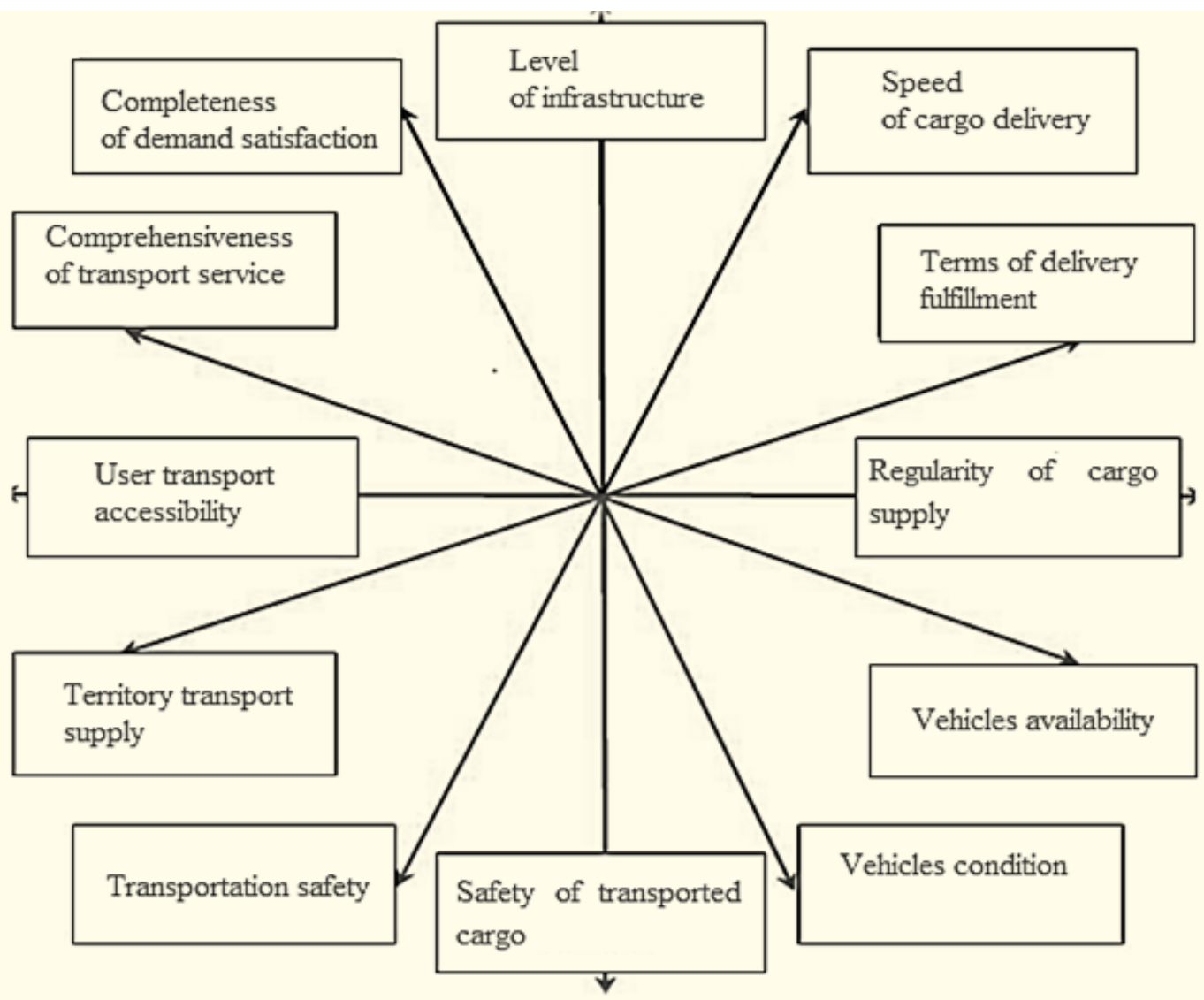

Fig. 5. System of indicators of transport service quality.

Source: Compiled by the authors

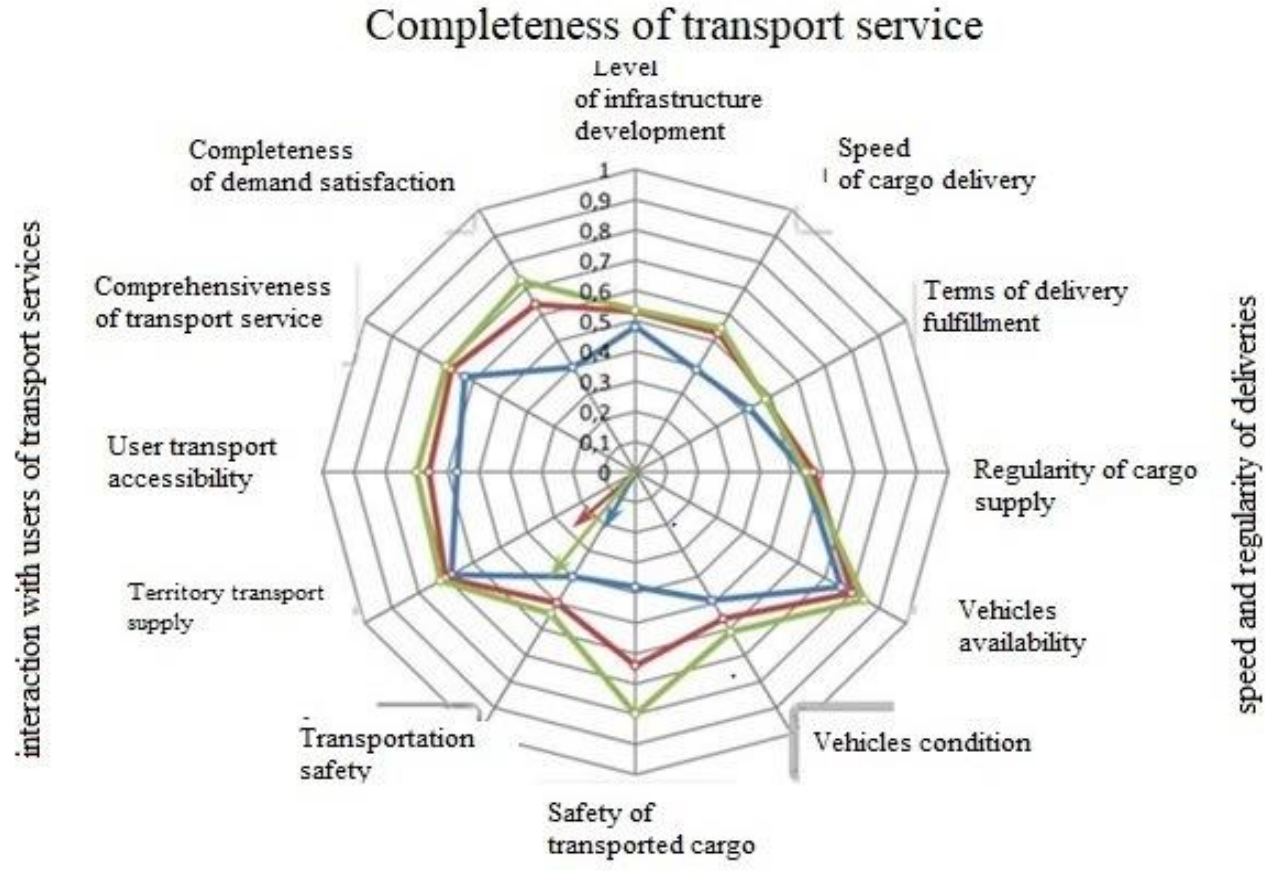

Transport service stability

$=2016-2017-2018$

Fig. 6. Dynamics of transport quality indicators

Source: Compiled by the authors 
The deviation of the projection of the total vector from the axis indicates the following:

- the segment with lagging growth dynamics in 2017 is shifting from indicators of completeness of transport service in the direction of indicators of speed and regularity of deliveries, and in 2018 it covers both of them, and at the same time this year the indicators of "completeness of demand satisfaction" and "safety of transported cargo" are growing significantly;

- the direction of the total vectors shows that the quality indicators that belong to the group "interaction with users of transport services" have improved to a greater extent than other indicators;

- the speed and regularity of deliveries, as well as the completeness of transport services, deserve more attention than the sustainability of transport services, which should be taken into account when designing measures to improve the competitiveness of freight services.

\section{Conclusions}

1. The proposed model for assessing the competitiveness of freight services allows to assess the competitiveness based on the quality of transport service, taking into account both the importance of individual quality indicators in the overall system and their various changes.

2. This model can be used to provide an indicative assessment of the quality of transportation in various segments of the freight market. In addition, one of the key strengths of the competitiveness assessment model is that the number of analyzed indicators that affect competitiveness is potentially unlimited.

3. It also allows us to assess the competitiveness both in terms of customer-centric approach and pricequality ratio, as well as from the position of the freight carrier enterprise taking into account the factors of transportation security and accessibility.

\section{References}

1.Vorkut T. A., Bilonog O. E., Dmitrychenko A. M., Tretinichenko Y. A. (2017). Supply Chain Management, Logistics Aspect: Teach. manual Kiev; NTU. 288.

2.Dragunova I. V. (2010). Assessment of competitiveness in services. Economic Journal. №19. 4348.

3.Zagursky O. M. (2019). Analysis of the market of motor transport services in Ukraine. Collection of scientific works "Road Transport". № 44. 66-71.

4.Zagursky O. M. (2019). Assessment of the transport services market of Ukraine. Machinery \& Energetics. Journal of Rural Production Research. Kyiv. Vol. 10. No. 1. 41-46.

5.Zaitsev E. P. (2017). Higher mathematics: linear and vector algebra, analytical geometry, introduction to mathematical analysis: textbook. tool. 2nd edition, stereotyped. Kyiv: Alerta. 574.

6.Zorina O. I., Sivolovskaya O. V. (2012). Methods for assessing the competitiveness of the transport service.
Electronic Scientific Professional Edition "Effective Economy". № 5 URL: http://www.economy.nayka. com.ua/?iid=1133\&operation $=1$.

7.Menger K. (2005). Selected Works. Moscow: Territory of the Future Publishing House. 496.

8.Shinkarenko V. G., Lazareva T. E. (2016). Assessment of the intensity of competition in the market of motor transport services. Economy of the transport complex: coll. Sciences. Kharkiv Ave. nat. car-do. un-t; Economy. Management. Innovation. Issue No. 4 (19). 60-77.

9.Seyoum B. (2007). Revealed comparative advantage and competitiveness in services. Journal of Economic Studies, 34 (5), 376-388.

10. Wenbin Sun, Jing Pang. (2017). Service quality and global competitiveness: Evidence from global service firms, Journal of Service Theory and Practice, Vol. 27 Issue 6, 1058-1080, URL: https://doi.org/ 10.1108/ JSTP-12-2016-0225.

\section{Список літератури}

1.Воркут Т. А., Білоног О. С., Дмитриченко А. М., Третиниченко $Ю . \quad O$. Управління ланцюгами постачань, логістичний аспект. Київ; НТУ, 2017. $288 \mathrm{c}$.

2.Драгунова И. В. Оценка конкурентоспособности в сфере услуг. Экономический журнал. 2010. № 19. С. 43-48.

3.Загурський O. М. Аналіз ринку автотранспортних послуг в Україні. Збірник наукових праць «Автомобільний транспорт». 2019. № 44. С. 66-71.

4.Загурський О. М. Оцінка ринку транспортних послуг України. Техніка та енергетика. 2019 Т. 10. № 1. С. 41-46.

5.3айщев $\epsilon$. П. Вища математика: лінійна та векторна алгебра, аналітична геометрія, вступ до математичного аналізу: навч. посіб. 2-ге видання, стереотипне. Київ: Алерта, 2017. 574 с.

6. Зоріна О. І., Сиволовскька О. В. Методи оцінки конкурентоспроможності транспортної послуги Електронне наукове фахове видання «Ефективна економіка». 2012. № 5 URL: http://www.economy. nayka.com.ua/?iid=1133\&operation $=1$.

7.Менгер K. Избраннье работы. Москва: Издательский дом «Территория будущего», 2005. $496 \mathrm{c.}$

8.Шинкаренко В. Г., Лазарєва Т. С. Оцінка інтенсивності конкуренції на ринку автотранспортних послуг. Економіка транспортного комплексу: зб. наук. пр. Харк. нац. автомоб.-дор. унт; Економіка. Управління. Інновації, 2016. Випуск № 4 (19), C. 60-77.

9. Seyoum B. Revealed comparative advantage and competitiveness in services. Journal of Economic Studies, 2007. 34(5), P. 376-388.

10. Wenbin Sun, Jing Pang Service quality and global competitiveness: evidence from global service firms, Journal of Service Theory and Practice, 2017. Vol. 27 Issue: 6, P. 1058-1080, URL: https://doi.org/10.1108/JSTP-12-2016-0225. 


\section{МЕТОД ОЦНКИ КОНКУРЕНТОСПРОМОЖНОСТІ АВТОТРАНСПОРТНИХ ПЕРЕВЕЗЕНЬ НА ОСНОВІ БАГАТОВИМІРНОЇ ВЕКТОРНОЇ МОДЕЛІ ПОКАЗНИКІВ ЯКОСТІ ТРАНСПОРТНОГО ОБСЛУГОВУВАННЯ \\ О. М. Загурський}

Анотація. Показники конкурентоспроможності транспортних послуг змінюються під впливом як внутрішньогалузевих факторів, так і кон'юнктури транспортного ринка й макроекономічної кон'юнктури. При цому в умовах безперевного підвищення якості i диференціації транспортних послуг компаній-конкурентів змінюються і вимоги, що висуваються вантажовласниками до автоперевізників.

В статті запропоновано новий метод оцінки конкурентоспроможності автотранспортного підприємства за показниками якості транспортного обслуговування. Розроблена модель дозволяє оцінювати конкурентоспроможності автотранспортного підприємства на основі показників якості транспортного обслуговування 3 урахуванням як значущості окремих чинників якості в загальній системі, так і їх різноспрямованих змін. Ця модель може бути використана для індикативної оцінки рівня якості перевезень на різних сегментах ринку вантажних перевезень.

Ключові слова: ефективність, конкурентоспроможність, вантажні перевезення, транспортні послуги, якість обслуговування.

\section{МЕТОД ОЦЕНКИ КОНКУРЕНТОСПОСОБНОСТИ АВТОТРАНСПОРТНЫХ ПЕРЕВОЗОК НА ОСНОВЕ МНОГОМЕРНОЙ ВЕКТОРНОЙ МОДЕЛИ ПОКАЗАТЕЛЕЙ КАЧЕСТВА ТРАНСПОРТНОГО ОБСЛУЖИВАНИЯ \\ О. Н. Загурский}

Аннотация. Показатели конкурентоспособности транспортных услуг изменяются под влиянием как внутриотраслевых факторов, так и конъюнктуры транспортного рынка и макроэкономической конъюнктуры. При этом в условиях непрерывного повышения качества и дифференциации транспортных услуг компаний-конкурентов меняются и требования, предъявляемые грузовладельцами к автоперевозчикам.

В статье предложен новый метод оценки конкурентоспособности автотранспортного предприятия по показателям качества транспортного обслуживания.

Разработанная модель которая позволяет оценивать конкурентоспособность автотранспортного предприятия на основе показателей качества транспортного обслуживания с учетом как значимости отдельных факторов качества в общей системе, так и их разнонаправленных изменений. Эта модель может быть использована для индикативной оценки уровня качества перевозок на различных сегментах рынка грузовых перевозок.

Ключевые слова: эффективность, конкурентоспособность, грузовые перевозки, транспортные услуги, качество обслуживания.
О. М. Загурський ORCID 0000-0002-5407-8466. 
